\title{
FHA AND FNMA ASSISTANCE FOR MULTIFAMILY HOUSING*
}

\author{
B. T. Fitzpatrick $\dagger$ \\ INTRODUCTION
}

When the Federal Housing Administration (FHA) was established in I934, its area of concern was mortgage financing in connection with single family, owner occupied homes. In I938 FHA was given its first legislative authorization to assist in financing multifamily housing through the enactment of section 207 of the National Housing Act, as amended. ${ }^{1}$ However, FHA was not a significant factor in this segment of the homebuilding industry until the Congress, by the enactment of section 608 in $1942,{ }^{2}$ granted it further authorization to assist multifamily housing during the Second World War. Thereafter, because multifamily housing was becoming an increasingly important means of meeting our total housing needs, Congress has, over the years, added a large number of new FHA authorizations to assist in enlarging the annual volume of needed multifamily housing. These new authorizations include cooperative and condominium housing, urban renewal housing, housing for families of low and moderate income, and housing for elderly persons.

These new multifamily housing programs have vastly increased the scope of FHA's responsibilities. Especially when combined with some of the special assistance powers of the Federal National Mortgage Association (FNMA), the FHA now has the powers to be a dynamic and potent influence in the field of multifamily housing production. The need for a future total annual housing production which is far in excess of our best previous production is well established; a much greater percentage of such total housing production must consist of planned, multifamily housing projects. This is an absolute requirement for the success of any real national effort toward marked improvement of our urban areas. Any evaluation of FHA's pro-

\footnotetext{
- This article was prepared prior to March 1967 and does not seek to review developments since that time.

† A.B. I930, Dartmouth College; LL.B. 1933, Harvard University. Member of the District of Columbia and Hawaii bars; Counsellor-at-Law, in private practice since 1955. Deputy Administrator and General Counsel, Housing and Home Finance Agency, 1947-1955; General Counsel and Associate General Counsel, National Housing Agency, 1942-r947; Counsel, Public Housing Administration and United States Housing Authority, I938-r942; Vice Chairman and Director, Defense Homes Corporation I946-47; Vice Chairman and Director, Federal National Mortgage Association, I950-1955. Author, The Private Redeveloper IN the Urban Renewal Program (i959), Contract Disposition Problems in Urban Renewal (ig6r), The Role of the Redeveloper in Urban Renewal (I96i), The Goals of Our National Housing Policies (I96r), Assistance for Colleges and Universities located in or Near Urban Renewai Areas (I96i), FHA Programs for Low Income Families (1965).

The author wishes to express his grateful appreciation to William S. Tennant, Esquire, of Krooth \& Altman, Washington, D.C., formerly Counsel, Urban Renewal Section, Office of the General Counsel, Fed. eral Housing Administration, for his helpful suggestions.

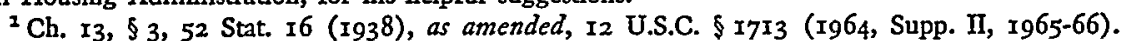

${ }^{2}$ Ch. 319, \$ Ir, 56 Stat. 303 (I942), as amerded, I2 U.S.C. \$ I743 (1964, Supp. II, 1965-66).
} 
grams for, and performance in, assisting multifamily housing production must be measured against these needs.

\section{I}

\section{General Basis for FHA Assistance}

All FHA multifamily housing programs are based on the insurance of long term (usually forty years), high ratio (90 per cent to Ioo per cent) mortgage loans at relatively low interest rates. In the case of new construction, the loan ratio, which varies between programs as well as types of mortgagors, is a percentage of project value or of project replacement cost. In the case of repair and rehabilitation, the loan ratio is based on the sum of the estimated cost of repair and rehabilitation and the Federal Housing Commissioner's estimate of the value of the property before such repair and rehabilitation, with a limitation that, where any such case involves refinancing existing indebtedness, the FHA-insured mortgage may not exceed the estimated cost of repair and rehabilitation plus the amount (as determined by FHA) required to refinance the existing indebtedness secured by the property to be repaired or rehabilitated.

Under existing law, the maximum interest rates are as follows: (r) sections $207^{3}$ and $213^{4}$ management type-5-1/4 per cent; (2) section $234^{5}$ condominiums $-5-1 / 4$ per cent on the blanket mortgage, but six per cent on the release out individual mortgages; (3) sections $220^{6}$ and $221^{7}$ market rate cases-six per cent; (4) section $23 \mathrm{I}^{8}$ $5-1 / 2$ per cent; and (5) section $22 \mathrm{I}$ (d) (3) ${ }^{9}$ below market interest rate cases-six per cent during construction and reduced at final endorsement (i.e., after completion of construction) to three per cent.

In the case of section 207 , the loan ratio is based on the FHA estimate of the value of the property when the proposed improvements are completed. In all other cases involving new construction, the loan ratios are based on the FHA estimate of the replacement cost of the project.

The value or the cost of the project may include the FHA's estimate of the fair market value of the land (prior to the construction of the improvements to be built as a part of the project) when owned in fee by the mortgagor, the proposed physical improvements, utilities within the boundaries of the property, architect's fees, taxes and interest (and, in leasehold cases, ground rent) during construction, and "other miscellaneous charges incident to construction and approved by the Commissioner." These latter charges include insurance during construction, premium on the contract bond, quantity survey, FHA fees (i.e., examination and inspection fees and mortgage insurance premiums during construction), financing expense not exceeding two per

\footnotetext{
${ }^{3} 12$ U.S.C. 5 713 (1964, Supp. II, 1965-66).

I2 U.S.C. 5 r7i5e (1964, Supp. II, 1965-66).

I2 U.S.C. \$ 1715y (1964, Supp. II, I965-66).

'I2 U.S.C. 5 I7r5k (1964, Supp. II, 1965-66).

7 I2 U.S.C. \& ririsl (1964, Supp. II, 1965-66).

8 I2 U.S.C. 5 I7I5V (1964, Supp. II, 965-66).

- 12 U.S.C. $\$$ I7rsl(d) (3) (Supp. II, Ig65-66).
} 
cent of the face amount of the mortgage, title and recording expense, legal and organization expense, and builder's profit. The builder's profit allowance and general overhead allowance is hereinafter discussed in greater detail.

In the case of cooperatives and condominiums under sections 213 and 234, there is also included an allowance for sales and marketing expense. In the case of nonprofit mortgagors (including cooperatives) under section $22 \mathrm{I}(\mathrm{d})(3)$ below market interest rate projects, there is also included in the estimate of project replacement cost the FNMA commitment fee of one per cent of the face amount of the mortgage. In all multifamily housing cases, FHA requires the mortgagor to escrow for working capital an amount equal to two per cent of the face amount of the mortgage. This can be in the form of cash or an unconditional irrevocable commercial letter of credit. However, for nonprofit mortgagors (including cooperatives) under section $22 \mathrm{r}(\mathrm{d})(3)$ below market interest rate cases, there is also included in the estimate of project replacement cost this two per cent working capital item-although, in FHA jargon, it is called an allowance to make the project operational (AMPO).

\section{II}

\section{Limitations on Maximum Amount of Loan}

There are several limitations on the maximum amount of the insured mortgage loan. They are (I) the ratio of loan to estimated value or replacement cost, (2) dollar limitations per dwelling unit and per type of mortgagor, and (3) debt service (i.e., the maximum mortgage supported by net income, determined by dividing ninety per cent to ninety-five per cent of net income by the sum of (i) mortgage interest rate, (ii) mortgage insurance premium and (iii) initial curtail factor). The loan to value ratios and dollar limitations vary depending on the section of the act and the type of mortgagor involved.

\section{A. Loan Ratios}

The loan ratios for the various programs are as follows:

(a) Section 207-ninety per cent of the value of the project.

(b) Section 213-ninety-seven per cent of estimated replacement cost in the case of management type cooperatives; ninety per cent estimated replacement cost in the case of an investor-sponsor (i.e., a mortgagor approved by FHA who, as a condition of obtaining mortgage loan insurance, certifies that upon completion of the project he intends to sell the same, at certified project cost, to a management type cooperative, such purchasing cooperative getting a ninety-seven per cent of project replacement cost loan).

(c) Section 22I-ninety per cent of estimated replacement cost in the case of limited distribution mortgagors; I00 per cent of estimated replacement cost in the case of cooperatives (including investor-sponsor cases), nonprofit mortgagors (including 
builder-sellers who, prior to submitting an application for mortgage insurance, have entered into an agreement with a nonprofit mortgagor eligible for a section 221 (d) (3) insured mortgage loan to sell the project at completion at certified project cost), or a public body not receiving financial assistance from the United States exclusively pursuant to the Housing Act of 1937. It is to be noted that in the case of investorsponsor and builder-seller mortgagors obtaining roo per cent loans under section $22 \mathrm{I}(\mathrm{d})(3)$, not less than ten per cent of such loan is escrowed or retained until the project is actually transferred to the purchasing cooperative or nonprofit mortgagor, at which time it is paid over to the investor-sponsor or builder-seller. If the project is not so transferred, such retention is applied to reduce the mortgage, and the investorsponsor or builder-seller mortgagor is required to operate as a limited distribution mortgagor.

(d) Section 234-ninety per cent of estimated replacement cost on the blanket mortgage.

(e) Section 23r-100 per cent of estimated replacement cost for nonprofit mortgagors; ninety per cent of estimated replacement cost for "profit motivated" mortgagors.

\section{B. Dollar Limitations Per Dwelling Unit}

Different dollar limitations are established for non-elevator and elevator type structures, and for various sections of the act, as shown below.

\begin{tabular}{|c|c|c|c|c|}
\hline & \multicolumn{2}{|c|}{$\begin{array}{l}\text { Sections } 207,213 \\
\text { and } 220\end{array}$} & \multicolumn{2}{|c|}{$\begin{array}{l}\text { Sections } 22 \mathrm{I}(\mathrm{d})(3) \\
22 \mathrm{I}(\mathrm{d})(4) \text { and } 23 \mathrm{I}\end{array}$} \\
\hline & $\overline{\text { Non-Elevator }}$ & Elevator & Non-Elevator & Elevator \\
\hline -BR & $\$ 9,000$ & $\$ 10,500$ & $\$ 8,000$ & $\$ 9,500$ \\
\hline $\mathrm{I}-\mathrm{BR}$ & 12,500 & $1_{5,000}$ & 11,250 & 13,500 \\
\hline $2-B R$ & 15,000 & 18,000 & 13,500 & 16,000 \\
\hline 3 or more $B R$ & 18,000 & 22,500 & 17,000 & 20,000 \\
\hline
\end{tabular}

The Commissioner may, by regulation, increase any of the above dollar limitations by not to exceed forty-five per cent in any geographical area where he finds that cost levels so require. Also, the dollar limitations shown for section $221(\mathrm{~d})(3)$ are applicable to the market rate program only. For the section $22 \mathrm{I}$ (d) (3) below market interest rate programs, special dollar limitations (as well as family income limitations for purpose of admission) are fixed by FHA on a community-by-community basis.

In connection with the dollar limitations established for section $23 \mathrm{I}$ elderly housing, there is a disadvantage, compared to section 207 or section 220 , of from $\$ 1,000$ to $\$ 2,500$ per unit. This disadvantage to section 23 I elderly housing is not based on facts as to cost. In fact, elderly housing costs more than the typical multifamily rental housing projects under sections 207 and 220 primarily because:

r. State licensing requirements require satisfaction of fire control standards far 
in excess of those applicable to such other multifamily rental housing projects. These take the form, for example, of smoke and heat sensing devices in both private and public areas; extra lighting; two means of egress from every apartment; fire retardant and resistant materials requirements;

2. Community facilities must be more extensive than in other multifamily rental housing projects. Ill-defined criteria pertaining to "nondwelling" qualifications of common areas may result in excessive dependence on "unit count" limitations. This condition causes either unnecessary disputes with local FHA insuring offices or apartment and public area design ill-suited to the elderly housing market. For example, elevators, hallways, laundry rooms, elevator lobbies, required exit stairs, smoke towers, janitor closets, maintenance shops, and general storage areas would be of the approximate same design and cost with each program. Under section 23I, however, there are numerous requirements for additional common areas in keeping with section E40I-3.I of the FHA Minimum Property Standards for Housing for the Elderly, which states:10 "Lounges and other rooms for social and recreational facilities are required and shall be provided to the extent needed to enhance living in the project." Other examples of these common areas required by housing for the elderly are linen rooms, maids' storage and day rooms, employees' rest rooms and women's cot rooms. FHA should make it clear that in section $23 \mathrm{I}$ cases all common areas (i.e., areas outside of dwelling units), except those which in a typical section 207 or section 220 project would normally be classified as required for dwelling purposes, are to be classified as nondwelling facilities.

\section{Dollar Limitations on Mortgage Amount}

These limitations are based on the type of mortgagor-public mortgagors and any other eligible mortgagors. In general, public mortgagors are defined as federal or state instrumentalities, municipal corporate instrumentalities of one or more states, or limited dividend or housing corporations (in section 2I3 cases, only "nonprofit" as distinguished from "limited dividend" corporations) restricted by federal or state laws or by regulations of state banking or insurance departments as to rents, charges, capital structure, rate of return or methods of operation. The applicable dollar limitations are as shown below:

$\begin{array}{ccc}\text { Section } & \text { Public Mortgagor } & \text { Other } \\ 207 & \$ 50,000,000 & \text { Eligible Mortgagor } \\ 213 & 25,000,000 & \$ 20,000,000 \\ 220 & 50,000,000 & 20,000,000 \\ 221 & 12,500,000 & 30,000,000 \\ 231 & 50,000,000 & 12,500,000 \\ 234 & 25,000,000 & 12,500,000\end{array}$

\footnotetext{
${ }^{10}$ U.S. Federal Housing Administration, Dep't of Hodsing and Urban Development, Miniajum

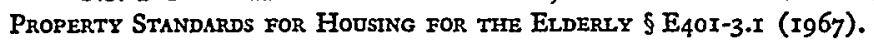


III

\section{Limitations on Commercial and Community Facidities}

The limitations on the type and extent of commercial and community facilities which may be included in multifamily housing projects vary considerably, depending on the section of the act involved. These limitations are as follows:

(a) Sections 207, 2I3, 23I and 234-Such commercial and community facilities ("special" instead of "community" in the case of section 23r) as the Commissioner deems adequate to serve the occupants.

(b) Sections 221 (d) (3) and 221 (d) (4)-Such commercial and community facilities as the Commissioner deems adequate to serve the occupants, except that in the case of any such property or project located in an urban renewal area, the provisions of section 220 apply to the nondwelling facilities which may be included in the mortgage if the mortgagor waives the right to receive dividends on its equity in the portion thereof devoted to community and shopping facilities.

(c) Section 220-Such nondwelling facilities as the Commissioner deems desirable and consistent with the urban renewal plan. However, the project must be predominantly residential, and any nondwelling facilities included in the mortgage must be found by the Commissioner to contribute to the economic feasibility of the project. Also, the Commissioner is required to give due consideration to the possible effect of the project on other enterprises in the community.

(d) General Comment-The restriction of commercial and community facilities strictly to those deemed necessary to serve the occupants militates against sound urban planning. It would appear that, if FHA is to advance rather than retard sound urban planning, the standards as to the inclusion of nondwelling facilities should approximate the present standards for section 220 .

IV

\section{Allowances for Builder's Profit and General Overhead}

\section{A. General}

There are two types of builder's profit allowance: the regular allowance, and the ten per cent allowance. The regular allowance is whatever the local FHA insuring office finds that contractors in the area would require as a construction fee to crect a comparable project. In general, this regular allowance will vary from about four per cent to seven per cent of estimated field construction cost. The ten per cent allowance has, in the main, been established by the Congress for certain programs at ten per cent of all project costs other than land.

\section{B. Regular Profit Allowance}

The regular profit allowance is applied in the following: (a) all section 207 projects; (b) section 213 projects in non-urban renewal areas; (c) section $22 \mathrm{I}(\mathrm{d})(3)$, 
all projects (including builder-seller mortgagors) except as noted in subpart $C$ below, whether market interest rate or below market interest rate; (d) section 23I, nonprofit mortgagors; and (e) all section 234 condominiums in non-urban renewal areas.

\section{Ten Per Cent Profit Allowance}

The profit allowance at ten per cent of all estimated projected costs other than land is applied in the following: (a) section $2 \mathrm{I} 3$ projects in urban renewal areas; (b) all section 220 projects; (c) section $22 \mathrm{r}$ (d) (3) limited distribution mortgagors (excluding builder-sellers) whether market interest rate or below market interest rate; (d) section $22 \mathrm{I}$ (d) (3) cooperatives (including investor-sponsors) located in urban renewal areas; (e) section $22 \mathrm{I}(\mathrm{d})(4)$; and (f) section $23 \mathrm{I}$ profit-motivated mortgagors.

The FHA has recently advised that its policy of including the ten per cent profit allowance for certain types of cases-see (a) and (d) above-"is presently being reviewed." This may mean that FHA might discontinue this policy, and make the regular profit allowance applicable in these cases.

A further word of caution needs to be asserted here in connection with the ten per cent profit allowance. While the particular section of the act, or FHA policy, may say, without qualification, that such ten per cent allowance is to be included in the estimate of project replacement cost for processing, the mortgagor, at project completion, is confronted with an inconsistency in section 227 of the Act ${ }^{11}$ relating to cost certification. The FHA insurance commitment is based upon an estimate of replacement cost. After project completion, however, the mortgagor must certify to FHA the actual cost of the project. If the approved percentage of actual certified cost equaled or exceeded the mortgage loan, no change need be made in the loan. However, if the mortgage loan exceeds the approved percentage of actual cost, the mortgage loan is reduced by the amount of such excess.

Under section 22\%, however, the ten per cent profit allowance may be included in certified cost in those cases (called "identity of interest" cases) "where the mortgagor is also the builder as defined by the Commissioner." It is, therefore, of critical importance in retaining the ten per cent profit allowance to be sure at initial loan closing that there is an identity of interest between the mortgagor and the general contractor. FHA says such an identity of interest will be construed to exist under any of the following conditions: $:^{\mathbf{1 2}}$

When there is any financial interest of the mortgagor in the general contractor; when one or more of the officers, directors or stockholders of the mortgagor is also an officer, director or stockholder of the general contractor; when any officer, director or stockholder of the mortgagor has any financial interest whatsoever in the general contractor; when the general contractor advances any funds to the mortgagor; when

11 12 U.S.C. 5 I7r5r (1964, Supp. II, I965-66).

12 U.S. Federal Housing Administration, A Handboox for FHA Multtfamily Projects 33 (ig65). 
the general contractor provides and pays on behalf of the mortgagor the cost of any architectural services or engineering services other than those of a surveyor, general superintendent, or engineer employed by a general contractor in connection with his or its obligations under the construction contract; when the general contractor takes stock or any interest in the mortgagor corporation as part of the consideration to be paid them; when there exist or come into being any side deals, agreements, contracts, or undertakings entered into or contemplated, thereby altering, amending, or cancelling any of the required closing documents except as approved by the Commissioner.

\section{Incentive Provisions}

In cases involving nonprofit corporations, the construction contract in all cases (except as otherwise approved by the Commissioner) must be a cost-plus-fixed-fee contract with a guaranteed maximum upset price. In such cases, however, there may be included in such construction contract a "savings incentive provision" whereby the contractor's fee may be increased by fifty per cent of the savings effected below the guaranteed price up to the point where the fee equals ten per cent of all costs other than land. The inclusion of such an incentive provision is also allowed in cooperative and condominium cases where a cost-plus construction contract is used.

\section{E. Builder's General Overhead}

In addition to the builder's profit allowance, the FHA includes an allowance for general overhead (as distinguished from job overhead, such as superintendents, field engineer to provide lines and grades for locating structures and utilities on the site, watchmen, temporary offices, telephone, supplies, temporary sheds, toilet, heat, water and power during construction, and so on). General overhead includes such items as office rent, fuel, lights, telephone and telegraph, stationery, office supplies, fire and liability insurance for the office, salaries of office employees, social security taxes, public liability insurance, workmen's compensation insurance, and unemployment compensation taxes for office personnel. Salaries of officers or executives of the general contractor may be included if, during the period for which the salary of such officer or executive is allowed, he performs a type or types of duties which would normally be performed by a nonexecutive employee and his salary is in line with what would be paid to such nonexecutive employee for the performance of the same services. The following scale percentage (based on estimated field construction cost) is used by FHA in determining the builder's general overhead allowance: (i) amounts up to $\$ \mathrm{x}, 000,000-$ three per cent; (ii) additional on amounts in excess of $\$ \mathrm{~T}, 000,000$ but not exceeding $\$ 2,000,000-$ two per cent; (iii) additional on amounts in excess of $\$ 2,000,000$ but not exceeding $\$ 3,000,000-$ one per cent; and (iv) additional allowance on amounts in excess of $\$ 3,000,000-$ one-half per cent. 


\section{OTHER LimItations}

There are other limitations which apply to some of the multifamily housing programs. Section 220 is available only in respect of mortgage loans covering properties located in urban renewal areas. Section $22 \mathrm{I}(\mathrm{d})(3)$ is available only in communities which have in effect a "workable program" for the elimination of slums and blighted areas $^{13}$ approved by the Secretary of Housing and Urban Development. Rent supplements are available only in communities where rent supplements are a part of the "workable program," or which submit evidence of official local approval for participation in the rent supplement program. Such official local approval is by resolution of the local governing body. If a workable program is in effect and does not contain express provision for participation in the rent supplement program, the community must submit a letter from the mayor stating that the workable program of the community contemplates federally-assisted housing of low income families, including housing under such programs as the rent supplement program. If a community once had a workable program under which it received federal assistance for urban renewal or public housing, rent supplements will not be available unless such workable program is reactivated and recertified by the Secretary.

\section{VI}

\section{INDIVIDUALS AS MORTGAgors}

Individuals may be mortgagors under FHA-insured mortgage loans without assuming personal liability on the note or mortgage. This is accomplished by including in the note and mortgage exculpatory language which precludes the mortgagee from exercising any right (other than the right to foreclose) to institute any action against the mortgagor for the payment of any sum of money due under the note or mortgage, and also precludes the mortgagee from seeking any deficiency judgment. Exculpatory provisions are also included in the Regulatory Agreement.

\section{VII}

\section{Operating Defictr Escrows}

In any case where FHA estimates that the rental housing market is such that a substantial period of time will be required before a project can be rented up to a "break-even" point, FHA may require, as a condition of insurance, that at final loan closing the sponsors (as distinguished from the mortgagor entity) shall place in escrow a stated sum to cover any operating deficits which may be incurred during a stated period, generally one or two years. With such a condition, the mortgagee (in order to assure that the loan could be finally closed) would ordinarily require

\footnotetext{
${ }^{18}$ Housing Act of 1949 , $\S$ IOI (a), 42 U.S.C. $\$ 145$ I(a) (I964).
} 
these funds to be escrowed in cash at initial loan closing. In order to avoid depositing such amount of cash at commencement of construction and leaving it idle for the two or three year construction period, the sponsors may enter into a contract with FHA that they will place such cash in escrow for such purpose at final loan closing, and furnish a bond from an acceptable surety guaranteeing performance of such contract.

\section{VIII}

\section{Change Orders}

It is an established fact that in any sizable construction job there will, during the course of construction, be necessary changes ordered in the work. Such necessary changes arise for a variety of reasons, including errors or omissions in the contract drawings and specifications, unanticipated subsoil conditions, and changes in market acceptability of certain items of equipment. In cases involving cooperatives or nonprofit corporations which, as a practical matter, are dependent on the FHA-insured mortgage loan and have no other funds, the cost of such necessary changes can be financed only if there happen to be savings in nonconstruction cost items, or by putting through other "deduct" change orders to offset such increased cost. This seems a very inefficient and hazardous method for dealing with this type of situation. It has been suggested that, in these types of cases, there should be included in the mortgage loan a contingency item of two per cent or three per cent which, subject to strict FHA control, could be used to financed any increased costs resulting from changes during construction deemed necessary by FHA. Thus far FHA has refused to take any such action.

\section{IX}

\section{FNMA Special Assistance}

The Federal National Mortgage Association possesses what are known as "special assistance" functions in connection with some of the FHA multifamily housing programs-principally section 213, section 220, section 22I(d)(3) below market interest rate, rent supplements, and section $22 x(d)(3)$ and (d) (4) where the housing is for displaced families.

The homebuilding industry operates with two types of mortgage money-interim, or short-term, construction loans and long-term, permanent financing. One type of lender desires to put his money out on short term, one to three year construction loans. He cannot keep it there for forty years, so he does not make the construction loan unless he has a "permanent take out"--that is, when the initial construction loan which he makes is fully disbursed and insured by FHA, another lender has a firm commitment to purchase that loan at a price. Also, in the case of section $221(d)(3)$ below market interest loans, the current six per cent interest rate during construction 
reduces to three per cent at final loan closing and no private source would be available to provide the permanent take out for such cases.

Under its special assistance functions, FNMA can provide the permanent take out for these loans by making a commitment to the construction lender: to purchase the loan from it when construction is complete and the construction loan has been fully disbursed and insured. For such services FNMA charges a commitment fee of one per cent of the face amount of the mortgage and, if the loan is ultimately delivered to FNMA, a purchase and marketing fee of one-half per cent of the face amount of the mortgage is also charged. The FNMA contract does not require the interim lender to deliver the loan to FNMA; thus, if during the construction period the mortgage market changes, the interim lender may be able to arrange for a take out from conventional sources. Also, if the loan covered by such commitment is not delivered to FNMA, three-fourths of the one per cent FNMA commitment fee is refunded.

In the case of section 22I(d)(3) below market interest rate cases, FNMA charges the one per cent commitment fee, but does not charge the one-half per cent purchase and marketing fee. FNMA will make commitments to purchase section $221(d)(3)$ market rate projects involving rent supplements. However, in these cases it will charge its regular fees of $\mathrm{x}-1 / 2$ per cent: one per cent commitment fee and one-half per cent purchase and marketing fee. All FHA-insured mortgages purchased by FNMA under its special assistance functions are purchased at par.

It is to be noted that in January I967, FNMA suddenly initiated discounts of from two per cent to four per cent on its mortgage purchases under some of its special assistance programs. These discounts, of course, would be in addition to the regular FNMA fees of $1-1 / 2$ per cent. This FNMA action seemed a violation of the mandate of the Congress expressed in the Conference Report on the Ig66 housing act which said:14 "While loans are purchased by FNMA at discounts under its regular secondary market, the conferees are strongly opposed to such discounts in the use of FNMA special assistance funds." After public criticism of this action by Congressman Patman, Chairman of the House Committee on Banking and Currency, and Congressman Barrett, Chairman of the Housing Subcommittee, FNMA rescinded this action and resumed par purchases for special assistance mortgages.

Also, it has recently come to light that the administration, during the fiscal year I967, has been impounding many of the authorizations previously made available by the Congress for various FNMA special assistance programs. For example, of the $\$ 450$ million projected for section $22 \mathrm{I}$ (d) (3) below market interest rate mortgages, the administration impounded all but $\$ 32.5$ million. For section $21_{3}$ cooperative housing, the administration impounded the entire $\$ 148$ million uncommitted balance in the revolving fund. These actions were taken without any prior notice; thus

\footnotetext{
14 H.R. Rep. No. 1868, 8gth Cong., 2d Sess. 3 (Ig66).
} 
developers who continued to act in reliance upon the continued availability of these authorizations have been disadvantaged.

Under the Housing Act of 1966 , FNMA was authorized to participate in the making of insured advances on the mortgage during construction up to ninety-five per cent of such advances. In other words, FNMA could agree to supply the interim lender with up to ninety-five per cent of funds required to make the construction loan. This authorization applies to any case where FNMA makes a commitment to purchase a mortgage insured under section 213, section 220 or under section 221 (d) (3) and executed by a cooperative (including an investor-sponsor), a limited dividend corporation, a private nonprofit corporation or association, or a builder-seller mortgagor. To date, the policy of the present administration has been not to allow FNMA to exercise this power.

\section{$\mathrm{X}$}

\section{Section 22I(D)(3) Below Market Interest Rate}

\section{A. In General}

Some additional comments are in order with respect to the section $22 x(d)(3)$ below market interest rate program. Notwithstanding the administration's current preoccupation with the rent supplement program, the below market interest rate program is regarded by many as the most important recent addition to the array of FHA multifamily housing programs. It is a "going" program today, most of the defects having been already overcome during its six year existence. It has strong acceptance and support in Congress. Experience has clearly demonstrated that it has substantially enlarged the area of housing needs of low and moderate income families which can be served by private rather than public enterprise. Developed to its full potential, the section 221 (d)(3) below market interest rate program can be the real savior to our cities.

In my view, if we are to have volume production under this program-and, certainly, this is a must-we are going to get it from the private, "for profit" developer source, rather than the nonprofit source. I do not mean that the nonprofit sources may not be appropriate for the ownership-management end; but, in general, as developers they are not so efficient as the typical private developer. The builderseller mortgagor, hereinafter described in more detail, can be a great help here.

Further, it seems to me that private limited distribution mortgagors have much to gain in this program. They are enabled to reach a market of vast proportions which, otherwise, they could not reach. The prospect of long rent-up periods and the cash drain of operating deficits is remote. The limited annual return of six per cent on the result obtained by multiplying the face amount of the mortgage by xr.II per cent is not unattractive if the cash outlay is relatively small. Tax advantages can be achieved in both construction and management periods. FHA needs to be out 
with a "hard sell" on the advantages of this program to the private limited distribution mortgagor.

\section{B. Waiver of FHA Mortgage Insurance Premium}

To further assist in achieving monthly rents or carrying charges which families of low or moderate income can afford to pay, the FHA has waived the requirement that the borrower pay the annual mortgage insurance premium, which amounts to onehalf per cent each year on the outstanding unpaid balance of the mortgage.

\section{Builder-Seller Mortgagors}

Nonprofit mortgagors frequently have motive, but neither money nor requisite skills. Someone has to help them through the intricacies of preparing and processing an FHA application. Someone has to find the funds to pay the costs and fees to get them up to the initial FHA loan closing. While it is possible for a builder to do this by loans or advances payable from the mortgage loan, if and when obtained, there always exists a problem of whether such a relationship creates an improper identity of interest which would make the nonprofit corporation ineligible to obtain an FHA insured loan.

Out of this problem came the "builder-seller" mortgagor. The nonprofit corporation is eligible for a roo per cent loan. Thus, a builder who, as a condition of securing an FHA commitment, signs a contract to sell the project on completion to a nonprofit corporation approved by the FHA, can get a commitment for a 100 per cent loan. If he does sell the project on completion to the nonprofit corporation, the full roo per cent loan is disbursed, and the nonprofit corporation merely assumes the loan and takes the completed project. If, for some reason, the builderseller fails to transfer the project to the nonprofit corporation, he is held to a maximum of a ninety per cent loan and restricted as a limited distribution mortgagor.

This is an over-simplification in respect to this type of mortgagor, but it is enough to indicate that there is a considerable amount of flexibility here which can permit very sensible and proper relationships to be worked out to the mutual benefit of nonprofit corporations and builders or developers, and, more important, to the mutual benefit of the low income people whom the FHA section $22 \mathrm{r}(\mathrm{d})(3)$ below market interest rate program is intended to help.

\section{Mortgage Limits and Income Limits}

In addition to the dollar limitations per dwelling unit fixed by the act and hereinbefore described, FHA administratively establishes dollar limitations per unit for zero, one, two, and three or more bedroom units. These limitations are fixed, from time to time, on a community-by-community basis. Typical current limitations are as follows: 


\begin{tabular}{lrrrr}
\multicolumn{1}{c}{ City } & $0-B R$ & $I-B R$ & $2-B R$ & $3-B R$ \\
Des Moines & $\$ 9,300$ & $\$ 13,250$ & $\$ 15,900$ & $\$ 19,850$ \\
New York City & 9,950 & 14,200 & 17,050 & 21,300 \\
Atlanta & 8,000 & 11,250 & 13,500 & 17,000 \\
Washington, D.C. & 9,850 & 14,050 & 16,850 & 21,100
\end{tabular}

Similarly, family income limitations are fixed by FHA, from time to time, on a community-by-community basis. Typical current limitations are as follows:

\begin{tabular}{lccccc}
\multicolumn{1}{c}{ City } & $I$ & 2 & $3-4$ & $5-6$ & 7 or more \\
Des Moines & person & persons & persons & persons & persons \\
New York City & $\$ 5,300$ & $\$ 6,500$ & $\$ 7,650$ & $\$ 8,800$ & $\$ 9,950$ \\
Atlanta & $5,75^{\circ}$ & 6,950 & 8,200 & 9,450 & 10,650 \\
Washington, D.C. & 4,350 & 5,250 & 6,200 & 7,150 & 8,050 \\
& 5,700 & 6,950 & 8,150 & 9,350 & 10,600
\end{tabular}

For purposes of determining eligibility, gross family income from all sources is considered.

\section{E. Provisions for Inclusion in Tenant Lease}

Under the regulatory agreement, tenant leases must contain clauses wherein the tenant (a) certifies the accuracy of the statements made in the application and income survey, (b) agrees that the family income, family composition, and other eligibility requirements shall be deemed substantial and material obligations of his tenancy, (c) agrees that if family income limitations for continuing occupancy, which may be established from time to time by the Commissioner, are exceeded the lease may be terminated, and (d) agrees that at such time as the landlord or Commissioner may direct he will furnish certification of the then-current family income.

\section{F. Spot Checks}

Not later than three months after initial occupancy, the local FHA insuring office must make a spot check to assure that initial occupancy requirements are being met. All violations must be reported to FHA Washington headquarters where action will be taken on an individual case basis. Any tenant who was ineligible at the time of initial occupancy must be evicted as soon as legally possible. The usual remedy imposed by Washington thus far is to require the sponsor to deposit, in a special account, the difference between the economic rent and the section $221(d)(3)$ rent for each month any such unit is occupied by an ineligible tenant. Disbursements from such special account can be made only with the prior written approval of FHA.

\section{G. Recertification of Tenant Income}

Two years after initial FHA permission to occupy, and each two years thereafter, tenant incomes must be recertified. On recertification, eviction or refusal to renew 
leases will not be required where (a) family income exceeds the limitations by no more than five per cent, or (b) the tenant agrees to pay an adjusted market rent.

Adjusted market rent is the rent that would be required if the interest rate on the mortgage loan were at a market rate and FHA was charging the one-half per cent mortgage insurance premium. It is computed by adding to the below market rents the lesser of the following: (i) twenty-eight per cent where the below market interest rate is three per cent, twenty-seven per cent where the below market interest rate is $3-1 / 8$ per cent, twenty-four per cent where the below market interest rate is $3-3 / 8$ per cent, nineteen per cent where the below market interest rate is $3-7 / 8$ per cent; or (ii) twenty-five per cent of the amount of excess family income over the maximum family income limitation. (If twenty-five per cent of the amount of such excess family income is less than $\$ 60$, no increase in rent payment is required.)

\section{H. Single Person Occupants}

The rg66 housing act provides that up to ten per cent of the dwellings in a project may be occupied by low and moderate income single persons who are less than 62 years of age. Otherwise, occupancy is limited to "families" and single persons who are 62 or older.

\section{XI}

\section{The Rent Supplement Program}

\section{A. In General}

While the administration did not propose it quite that way, when Congress finished working its will upon the rent supplement program it turned out to be a system whereby private housing enterprise would be enabled to provide some housing for families and individuals who otherwise would, in most cases, have to look to low rent public housing in order to secure decent, safe, and sanitary housing.

In its simplest terms, the rent supplement program is one whereby the federal government will pay over each month for the benefit of eligible families or individuals a sum equal to the difference between twenty-five per cent of one-twelfth of the annual gross income of such family or individual and the FHA-approved monthly shelter rent for the dwelling unit occupied by such family or individual. The rent supplement is to make up the difference between the amount which a low income family or individual can afford to pay for housing, and the actual economic rent to be charged in a privately owned and operated multifamily housing project financed with the assistance of a mortgage loan insured under the FHA section $221(\mathrm{~d})(3)$ market interest rate program. Historically, the generally accepted rule of thumb adopted by housing agencies has been that a family can afford to pay twenty per cent to twenty-five per cent of annual income for housing expense. 


\section{B. FNMA Fees and Discounts}

As previously indicated, for the rent supplement program FNMA charges its regular $I-1 / 2$ per cent fees. In addition, in the tight money market, the fees required by the interim lender run four per cent or five per cent. In the FHA estimate of replacement cost only two per cent is allowed for financing charges. Nonprofit mortgagors will have to supply cash for all financing fees or discounts in excess of two per cent.

\section{Maximum Rents}

FHA has established a schedule of maximum gross monthly rents and has indicated that, in high cost areas, the maximum rentals may be increased up to twenty-five per cent. The range of maximum rentals would be as follows:

Unit Size
o-BR
I-BR
2-BR
3-BR

Monthly Rent Range
$\$ 85-\$ 106$
I05- 130
I20- I50
I40- I75

Also, the FHA has clearly stated that these are maximum rents. Accordingly, in areas where suitable housing can be produced for lower rentals, this will be required. This means that the rents approved by the FHA will be the lower of (i) the rents set out in the maximum rent schedule or (ii) the rents needed to meet debt service, operating expenses and the maximum allowable return to a limited distribution mortgagor of six per cent per annum on the result obtained by multiplying the face amount of the mortgage by II.II per cent, or, in the case of nonprofit mortgagors, a residual income of five per cent, which will be used as a special contingency reserve. Rents are gross rents and must include all utilities except telephone.

In the case of welfare tenants, the amount of rent paid by the tenant shall be not less than the higher of the following amounts: (i) the rental allowance provided by the welfare agency, or (ii) twenty-five per cent of total household income, including welfare assistance payments.

\section{Eligible Tenants}

Those eligible to be accepted as tenants are any families or individuals who have incomes which would make them eligible for low rent public housing, as such incomes are established by the Federal Housing Commissioner, and who, in addition, meet any one of the following five qualifications: (a) he has been displaced by governmental action, (b) either he or his spouse is 62 years of age or older, (c) either he or his spouse is physically handicapped, (d) he now lives in substandard housing, or (e) he occupies, or did occupy, housing extensively damaged, or destroyed, by a 
natural disaster in an area determined by the Small Business Administration, since April I, 1965, to be a disaster area.

In determining tenant eligibility, gross income from all sources, before taxes or withholding, of all members of the household must be counted. This includes the income of children or ather dependents who will live in the unit. No deductions from gross income are allowed for dependents. In addition to income limitations, there are asset limitations-no more than $\$ 2,000$, except in the case of elderly persons, in which event assets may not exceed $\$ 5,000$.

\section{E. Amount of Rent Supplement}

The basic amount of the rent supplement is the difference between one-twelfth of twenty-five per cent of the gross income and the monthly rent. However, in no case may the amount of the rent supplement exceed seventy per cent of the monthly rent, and it must also be not less than ten per cent of the monthly rent.

While no deductions from gross income are permitted in determining tenant eligibility, the following deductions from gross income are permitted in determining the amount of the rent supplement to which the tenant is entitled: (a) up to $\$ 300$ of income earned by each member of the family under 18 years of age, (b) continuing costs (as determined by FHA) attributable to a permanent disability or a chronic illness not compensated by insurance or otherwise, and (c) expenses incurred for the case of children under thirteen years of age if necessary to the employment of a wage earner in the household.

\section{F. Income Certification and Recertification}

Each family or individual who is to occupy a rent supplement dwelling unit must fill out FHA Form 25or, the income and asset certification. The housing manager and his staff will have to help each such tenant to do this. On each anniversary of the date of such first income certification, each tenant, except elderly tenants, must recertify income; and the rent supplement payment will be adjusted on the basis of each such recertification.

The tenant, in his lease, must agree to report immediately any increase in income which will result in a monthly income of four or more times the monthly rental. In such case the rent supplement will be cut off. Otherwise, adjustment in the rent supplement will be made only after each annual recertification. Where a tenant's income decreases due to illness, loss of job or other hardship beyond his control, the FHA may grant a temporary increase in the rent supplement payments for such tenant.

\section{G. The Rent Supplement Contract}

The rent supplement contract (FHA Form 2503) will be based on the estimate of the amount of rent supplements required for the units in the project to be supple- 
mented. At the end of the rent-up period, however, FHA will adjust the original estimate to reflect the actual rent supplement requirements plus a contingency allowance of ten per cent. In general, it is intended that future adjustments would be within this ten per cent allowance factor.

Obviously, however, things can occur which could go beyond this ten per cent allowance factor. One would be increases in taxes and other operating expenses in the future. If FHA does not have authorization to increase rent supplements along with increased rents, this could cause serious trouble.

In a mixture of economically and culturally differentiated families, there is a "tipping point"-that is, a point at which, when some given percentage of units are occupied by less economically and culturally privileged families, the achievement of the desired occupancy becomes impossible. This tipping point will vary with the nature of the surrounding community, with the competitive desirability of the dwellings and their rents, and similar matters. If there is any guiding principle which can be suggested it would be that the greater the social and economic distance between the rent supplemented tenants and the non-rent supplemented tenants, the lower the tipping point will be.

Bearing this in mind, suppose that a project starts with fifty per cent of the units supplemented and fifty per cent non-supplemented. After a year or two, suppose the fifty per cent non-supplemented, or a large majority of them, move out and the vacancies cannot be filled at economic rents. Either FHA finds some more rent supplement money or the project defaults. To cover these types of contingencies, FHA undoubtedly will reserve some portion of its rent supplement authorization.

\section{H. Type of Project}

The FHA requirements are that all rent supplement projects shall be of modest design and that "swimming pools, two bathrooms per unit, air conditioning, and similar items will not be permitted." FHA also says that "projects should ... not have features that will contribute to premature obsolescence." These requirements are certainly contradictory.

If there are geniuses among the developers-and there are-who can produce projects, within the maximum rents allowed, which have swimming pools, air conditioning, two bathrooms for units to house six or eight persons, why should anyone forbid it, especially in the light of the admonition against features which contribute to premature obsolescence. In this connection, it would also be well to keep in mind that this rule means that such amenities will not be available for non-rent supplement tenants, and that this could well make the rental of those units difficult

\footnotetext{
${ }^{10}$ U.S. Federal Housing Administration, Dep't of Housing and Urban Development, Rent Supplement Program, Public Information Gutde and Instruction Handiook 2 (1966). (Emphasis added.)
} 
or impossible. It will also make most difficult the accomplishment of the objective of achieving an economic mix of families in rent supplement projects.

\section{Operating Expenses}

The FHA Handbook states: ${ }^{16}$

An allowance will be made in the operating cost for expenses incurred by management in certifying and recertifying of tenants for rent supplement eligibility, and for other administrative requirements imposed by the rent supplement program; and typical costs for providing managerial services in connection with housing for low income tenants.

The usual sources of data may not be applicable .... Public housing experience in the area should be examined ....

For all public housing projects, the national management costs-which they call administration expense-is \$7.Io per dwelling per month. Administration expense includes salaries, supervisory and clerical personnel, legal expense, travel, purchase of publications, membership dues and fees, telephone and telegraph expense, and sundry office expense, exclusive of employee benefits. Although the national average is $\$ 7.10$, the range is from $\$ 5.14$ to $\$ 8.59$.

There are other available public housing data which indicate the nature of the problems to be met in rent supplement housing. Of the public housing tenant population, thirty-six per cent of the families with children are one-parent, broken families; thirty per cent are elderly; fifty-three per cent are nonwhite; fifty per cent are receiving assistance benefits; eighty-two per cent of the elderly and twenty-five per cent of the non-elderly have no gainfully employed worker in the family.

The difference between the income limits established for the section 22I(d)(3) below market rate program and the rent supplement program is significant. For Washington, D.C., two-person families in rent supplements are at $\$ 3,500$ compared to about $\$ 7,000$ for section 22I(d)(3) below market; and seven or more-person families at $\$ 4,500$ in rent supplements compared with $\$ 10,600$ for section $22 \mathrm{I}$ (d)(3) below market. Roughly, the income limits for section $22 \mathrm{r}(\mathrm{d})(3)$ below market rate are double those for rent supplements.

\section{J. Occupancy Interviews}

Drawing further on public housing experience, as reflected in recent remarks of Abner Silverman, Assistant Commissioner for Management of the former Public Housing Administration, attention should be directed to some general but quite pertinent information on occupancy interviews and classification of tenant types.

The sponsor had best schedule appointments for interviews. If it is left up to the applicant to drop in at any time convenient for him or her, there will not only be an uneconomic bunching up of applicants, but also long waiting periods in which chil-

\footnotetext{
${ }^{10}$ Id. at 9.
} 
dren grow restless, parents' tempers fray, and anything but the proper attitude for a friendly, communicative interview will be created.

Even on a scheduled basis, the sponsor should be ready to cope with children in the application office. Low income mothers are not able to leave the children home with the maid, and parking them with neighbors may not be feasible. Since mothers are the usual applicant spokesmen for the families, the children perforce will have to come along, and they do not stay darling indefinitely.

Should the sponsor wish to interview both father and mother together, some consideration should be given to night office hours. For some wage earners, the interview may involve the loss of a day's pay; it does not seem necessary to put this burden on a low income family merely because of conventional concepts about office hours.

\section{K. Rough Classification of Tenant Types}

\section{The Mobile}

These consist of parents and children both of whom are capable of social advancement and improved income. They are characterized, usually, by a stable marriage, by the presence of a skilled or semi-skilled dependable wage earner, personal vigor and drive, eagerness to improve the lot of their children, and great self-respect. They need some help, but they are capable of being influenced by their neighbors. They will seek to emulate and aspire to the same level of achievement-provided only that the social distance between them and their neighbors is not so great that it precludes realistic aspirations.

The type of help they need is knowledge about programs that can assist them in improving their skills, and encouragement to participate in those programs and in other resident or neighborhood activities. The programs may range from vocational training, extension services, household management clinics, adult illiteracy, health service, youth employment-to any one of the many programs that go on in almost every community. Sympathetic, competent management will not only tell them about such programs, but it will also bring them to the project site, and get these tenants interested.

\section{The Partially Mobile}

These consist of a parent or parents who may be non-mobile but whose children are capable of advance. This group is very difficult to help; its need for services runs not only through the entire range of health, educational, welfare, and recreational activities now established, but through some as yet unformulated, or which are now being tested in local community action programs funded by the Office of Economic Opportunity.

Among the more obvious services are day care centers for the children of working mothers, intensive family counselling, intensive household and money management 
instruction, special tutoring programs for children, vocational rehabilitation services, mental and physical health clinical services, work experience programs, employment services, legal aid and advice-the "works."

These services must be brought into the neighborhood because, by and large, the members of this group are block-bound. They will not travel out of a familiar neighborhood to get to the services. They are also proud and shy and unwilling to expose their inadequacies to strangers. But if the programs are brought close to home, if the other participants are familiar figures, there is a chance these programs will succeed.

\section{The Non-Mobile}

These consist primarily of the elderly and the physically or mentally handicapped. These are the poor who will not enjoy any significant increase in income resulting from their effort, and for whom the prognosis must be that they will need constant and probably progressively increasing support and service as their capacities fail.

These latter considerations serve to point up a fact which is critical in the success of the rent supplement program. The housing of low income families is not merely a physical activity. It is part and parcel of the larger concept of the elimination of poverty. Management must therefore be a social as well as a physical process. A sponsor who accepts public aid to carry out a public purpose must accept the whole public purpose, not just the parts which are easiest to fulfill. Any sponsor who is unable or unwilling to accept and carry out these social management responsibilities should stay out of the rent supplement program.

\section{XII}

\section{Bastc Purpose of FHA}

It seems clear that the basic purpose of FHA is to enlarge the area of total housing need which can be served effectively by private, rather than public enterprise. If FHA is to take only such risks as are accepted by the typical conventional mortgage lender, then FHA cannot serve that basic purpose. Further, FHA's contribution toward enlarging the area of total housing need which can be served effectively by private enterprise must certainly be something more than merely enabling conventional mortgage lenders to make mortgage loans with longer terms and higher ratios. If FHA is to serve its basic purpose, it must accept a higher risk of default. To the extent that it fails to do so, it increases the pressure for extending the area of total housing need to be served by public endeavor. The need for FHA to accept a higher risk of default should be understood and accepted by the administration and the Congress.

The chart included herein as table I shows that, out of total FHA insurance written covering $1,160,772$ dwelling units in multifamily housing, only II4,844, or about ten per cent have gone into default. This is a relatively low default ratio. 


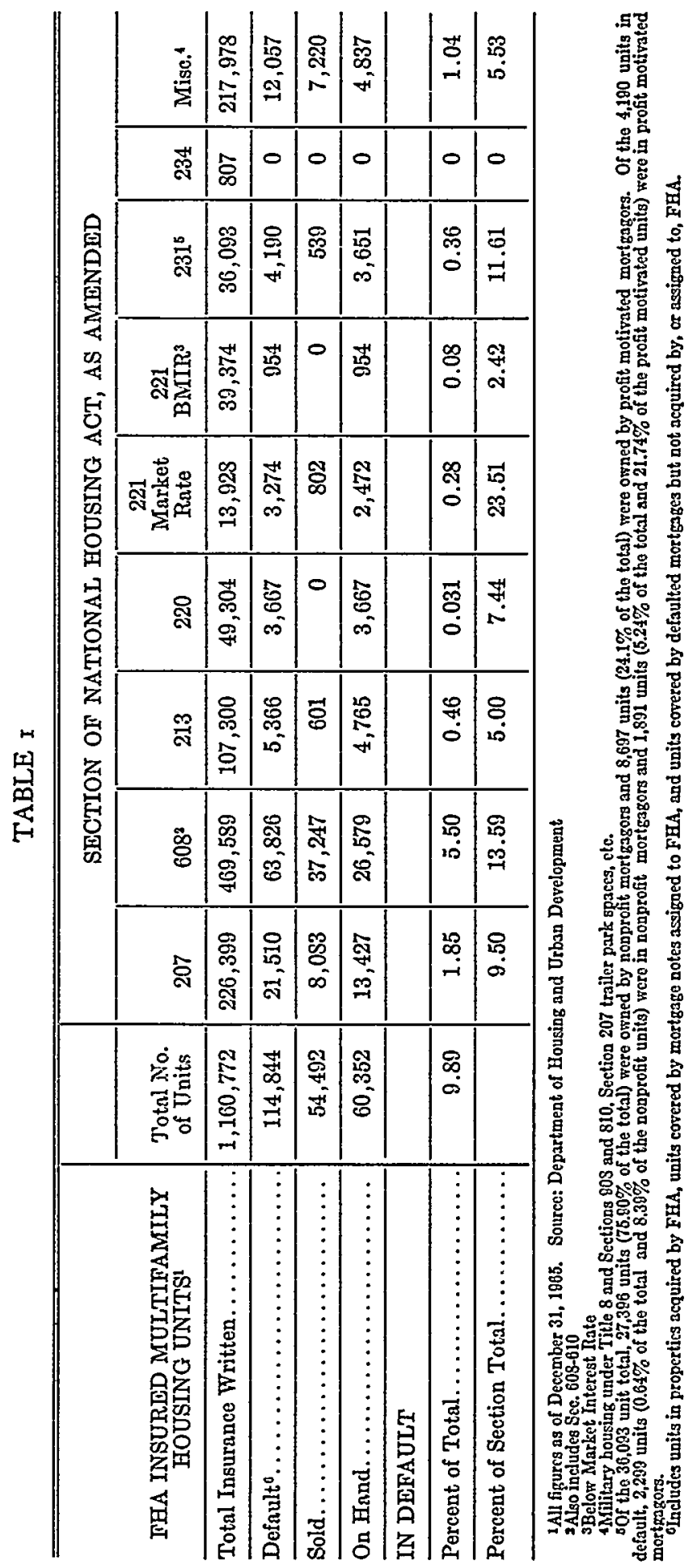


In the case of section 608 which produced the largest volume of multifamily housing, 63,826 , or about thirteen and a half per cent, of the 469,589 total units have gone into default. Nevertheless, the section 608 insurance fund remains one of the strongest FHA insurance funds.

It should be understood that "default" and "loss" are not coextensive. After a project financed with an FHA insured mortgage loan goes into default, FHA acquires it through assignment or foreclosure. After such acquisition, FHA manages the project until such time as, in its determination, sufficient occupancy is achieved to warrant sale of the property. The difference between (i) the price FHA receives at such sale and (ii) the outstanding balance of the mortgage at the time of default, plus the cost of any capital improvements in the project made by FHA during its management, is the "loss." The amounts collected by FHA from mortgage insurance premiums have been more than adequate to offset the actual losses sustained.

\section{XIII}

\section{FHA Beneftr to the Housing Consumer}

FHA participation in multifamily housing does result in substantial benefits to the housing consumer. As a rough rule of thumb, a project financed with a typical conventional loan would require average rents fifteen per cent to twenty per cent higher than the average rents required if the project was financed with an FHA section 220 insured mortgage loan. For purposes of illustration, assume that there is a market demand sufficient to permit a project with average rentals at \$200 per month with conventional financing. If the same project was financed with the assistance of a mortgage loan insured by FHA under section 220, the same facilities can be offered with average rents of $\$ 160$ to $\$ 170$ per month. The other alternative is that $\$ 30$ to $\$ 40$ more in average rents under the FHA formula will support an additional $\$ 3,500$ to $\$ 4,500$ more per unit in improved or additional amenities. In either event the benefit to the housing consumer is substantial-he can get the same product at considerably lower rents, or he can get a considerably better product at the same or somewhat lower rents.

\section{XIV}

\section{The Future-Short Run and Long Run}

To a large extent housing demand is made up of new household formations and demolition of existing dwelling units. Since r 964 , the gap between new household formations plus demolitions (highways, urban renewal, code enforcement, fire and other disasters, and so on) and housing starts has been increasing. In 1967 vacancies will probably hit the lowest point since 1958 . Demolitions are at an annual rate of about 700,000 and will likely increase. New household formations run about I.2 million a year, and will continue at not less than this rate in I968 and 1969 . This translates into a market demand for about 2 million dwelling units a year just to 
TABLE 2

\begin{tabular}{|c|c|c|c|c|c|c|c|c|c|c|c|c|c|c|c|c|c|}
\hline \multirow[b]{3}{*}{ YEAR } & \multirow{3}{*}{$\begin{array}{l}\text { Total } \\
\text { Private } \\
\text { Nonfarm } \\
\text { Housing } \\
\text { Starts }\end{array}$} & \multirow{2}{*}{\multicolumn{2}{|c|}{ 1-2 Family }} & \multirow{2}{*}{\multicolumn{2}{|c|}{$\begin{array}{c}\text { Multifamily } \\
3 \text { or More } \\
\text { Units }\end{array}$}} & \multicolumn{6}{|c|}{ FHA ASSISTED } & \multirow{2}{*}{\multicolumn{2}{|c|}{207}} & \multirow{2}{*}{\multicolumn{2}{|c|}{608}} & \multirow{2}{*}{\multicolumn{2}{|c|}{213}} \\
\hline & & & & & & \multicolumn{2}{|c|}{ TOTAL } & \multicolumn{2}{|c|}{ 1-4 Family } & \multicolumn{2}{|c|}{ Multifamily ${ }^{b}$} & & & & & & \\
\hline & & No. & $\begin{array}{l}\% \text { of } \\
\text { Col. } 2\end{array}$ & No. & $\begin{array}{c}\% \text { of } \\
\text { Col. } 2\end{array}$ & No. & $\begin{array}{l}\% \text { of } \\
\text { Col. } 2\end{array}$ & No. & $\begin{array}{l}\% \text { of } \\
\text { Col. } 3\end{array}$ & No. & $\begin{array}{c}\% \text { of } \\
\text { Col. } 4\end{array}$ & No. & $\begin{array}{l}\% \text { of } \\
\text { Col. } 7\end{array}$ & No. & $\begin{array}{l}\% \text { of } \\
\text { Col. } 7\end{array}$ & No. & $\begin{array}{l}\% \text { of } \\
\text { Col. } 7\end{array}$ \\
\hline (1) & (2) & (3) & & (4) & & (5) & & (6) & & (7) & & & & & & & \\
\hline 1966........ & $1,197.2$ & 812.4 & $68 \%$ & 384.8 & $32 \%$ & 158.4 & $13 \%$ & 129.1 & $16 \%$ & 29.3 & $8 \%$ & 2.9 & $10 \%$ & & & 4.3 & $15 \%$ \\
\hline $1965 \ldots \ldots \ldots$ & $1,482.7$ & 989.8 & 67 & 492.9 & 33 & 196.6 & 13 & 159.9 & 16 & 36.7 & 7 & 7.3 & 20 & & & 4.7 & 13 \\
\hline 1964.. & $1,530.4$ & 998.0 & 65 & 532.4 & 35 & 204.6 & 13 & 154.0 & 15 & 50.7 & 25 & 11.0 & 22 & & & 7.0 & 10 \\
\hline $1963 . . . \ldots \ldots$ & $1,581.7$ & 1046.4 & 66 & 535.3 & 34 & 221.0 & 14 & 166.2 & 16 & 54.9 & 10 & 27.1 & 49 & & & 7.1 & 13 \\
\hline 1962.. & $1,439.0$ & 1016.9 & 71 & 422.1 & 29 & 259.5 & 18 & 197.3 & 19 & 62.2 & 15 & 28.3 & 45 & & & 10,0 & 10 \\
\hline $1961 . .$. & $1,284.8$ & 990.0 & 77 & 294.8 & 23 & 243.6 & 19 & 198.8 & 20 & 45.0 & 15 & 23.5 & 52 & & & 0.8 & 22 \\
\hline $1960 .$. & $1,230.1$ & 1016.7 & 83 & 213.4 & 17 & 260.9 & 21 & 225.7 & 22 & 35.2 & 16 & 17.7 & 50 & & & 8.0 & 23 \\
\hline $1959 .$. & $1,494.6$ & $\begin{array}{r}1267.7 \\
\text { EST }\end{array}$ & $\begin{array}{c}85 \\
\text { IMATE }\end{array}$ & $\begin{array}{l}226.9 \\
\mathrm{~S}\end{array}$ & 15 & 332.5 & 22 & 307.0 & 24 & 25.4 & 11 & 12.3 & 48 & & & 4.4 & 17 \\
\hline 1958. & $1,314.2$ & 1144.0 & 87 & 170.0 & 13 & 295.4 & 22 & 270.3 & 24 & 25.1 & 10 & 14.0 & 58 & & & 0.8 & 27 \\
\hline $1957 .$. & $1,174.8$ & 1055.0 & 90 & 120.0 & 10 & 168.4 & 14 & $1 E 0.1$ & 14 & 18.3 & 15 & 3.7 & 20 & & & 9.4 & 51 \\
\hline $1956 \ldots \ldots$ & $1,324.9$ & 1245.0 & 84 & 80.0 & 6 & 189.1 & 14 & 183.4 & 15 & 5.8 & 7 & .4 & 7 & & & 3.4 & 60 \\
\hline $1955 .$. & $1,626.8$ & 1542.0 & 95 & 85.0 & 5 & 276.7 & 17 & 268.7 & 17 & 8.0 & $\mathbf{9}$ & 4.2 & 52 & & & 1.6 & 10 \\
\hline $1954 . .$. & $1,531.8$ & 1442.0 & 94 & 90.0 & 6 & 276.3 & 18 & 250.9 & 17 & 25.4 & 28 & 11.8 & 47 & & & 0.2 & 24 \\
\hline 1953... & $1,402.1$ & 1307.0 & 93 & 95.0 & 7 & 252.0 & 18 & 216.5 & 17 & 35.5 & 37 & 7.5 & 21 & .2 & $1 \%$ & 8.0 & 22 \\
\hline 1952.. & $1,445.4$ & 1360.0 & 94 & 85.0 & 6 & 279.9 & 19 & 229.1 & 17 & 50.8 & 60 & 7.3 & 14 & 5.0 & 12 & 10.1 & 20 \\
\hline 1951.. & $1,419.8$ & 1330.0 & 94 & 90.0 & 6 & 263.5 & 19 & 186.9 & 14 & 76.6 & 85 & 4.7 & 6 & 30.8 & 52 & 7.7 & 10 \\
\hline $1950 . .$. & $1,808.1$ & 1748.0 & 92 & 160.0 & 8 & 486.7 & 26 & 328.2 & 19 & 158.4 & 89 & 2.3 & 1 & 143.3 & 90 & .1 & 一 \\
\hline 1949.... & $1,429.8$ & 1270.0 & 89 & 160.0 & 11 & 363.8 & 25 & 252.6 & 20 & 111.2 & 70 & .8 & 1 & 110.0 & 98 & & \\
\hline 1948.... & $1,344.0$ & 1239.0 & 92 & 105.0 & 8 & 294.1 & 22 & 216.4 & 17 & 77.6 & 74 & & & 77.8 & 100 & & \\
\hline $1947 .$. & $1,265.1$ & 1195.0 & 94 & 70.0 & 6 & 229.0 & 18 & 178.3 & 15 & 50.8 & 73 & & & 50.8 & 100 & & \\
\hline 1946. & $1,015.2$ & 965.0 & 95 & 50.0 & 5 & 69.0 & 7 & 67.1 & 7 & 1.9 & 4 & & & 1.8 & 100 & & \\
\hline 1945.. & 324.9 & 310.0 & 95 & 15.0 & 5 & 41.2 & 13 & 38.9 & 13 & 2.3 & 15 & .2 & 9 & 2.1 & 01 & & \\
\hline $1944 .$. & 225.0 & 210.0 & 93 & 15.0 & 7 & 93.3 & 41 & 83.6 & 40 & 9.7 & 65 & & & 9.7 & 100 & & \\
\hline $1943 . \ldots$ & 300.0 & 270.0 & 90 & 30.0 & 10 & 146.2 & 49 & 126.1 & 47 & 20.0 & 67 & & & 20.0 & 100 & & \\
\hline $1942 . .$. & 450.0 & 420.0 & 93 & 30.0 & 7 & 165.7 & 37 & 160.2 & 38 & 5.5 & 18 & 1.2 & 22 & 4.3 & 78 & & \\
\hline $1941 . . . . .$. & 925.0 & 865.0 & 94 & 60.0 & 6 & 220.4 & 24 & 217.1 & 25 & 3.3 & 6 & 3.3 & 100 & & & & \\
\hline $1940 \ldots$ & 800.0 & 745.0 & 93 & 55.0 & 7 & 180.1 & 23 & 176.6 & 24 & 3.4 & 6 & 3.4 & 100 & & & & \\
\hline
\end{tabular}

keep up, and does nothing to make up the shortage accumulated in prior years. In 1966 , housing production was down to less than 1.2 million dwelling units, and in 1967 could, in the views of some, drop to about I million. This means that, in the short run period, we are leaving an annual shortage of 800,000 to $x, 000,000$ dwellings units a year.

By the year 2000, our urban population will double. In the next thirty-three years we will have to build as many dwelling units as were built in the last 200 years; and it is abundantly clear that of what we must build, for both the short and the long run, a much greater percentage of the total must be in multifamily housing projects.

\section{$\mathrm{XV}$}

\section{FHA's Performance}

It is against this background of need, both short run and long run, and this vast array of FHA powers to assist in the development of multifamily housing that we 
TABLE 2 (continued)

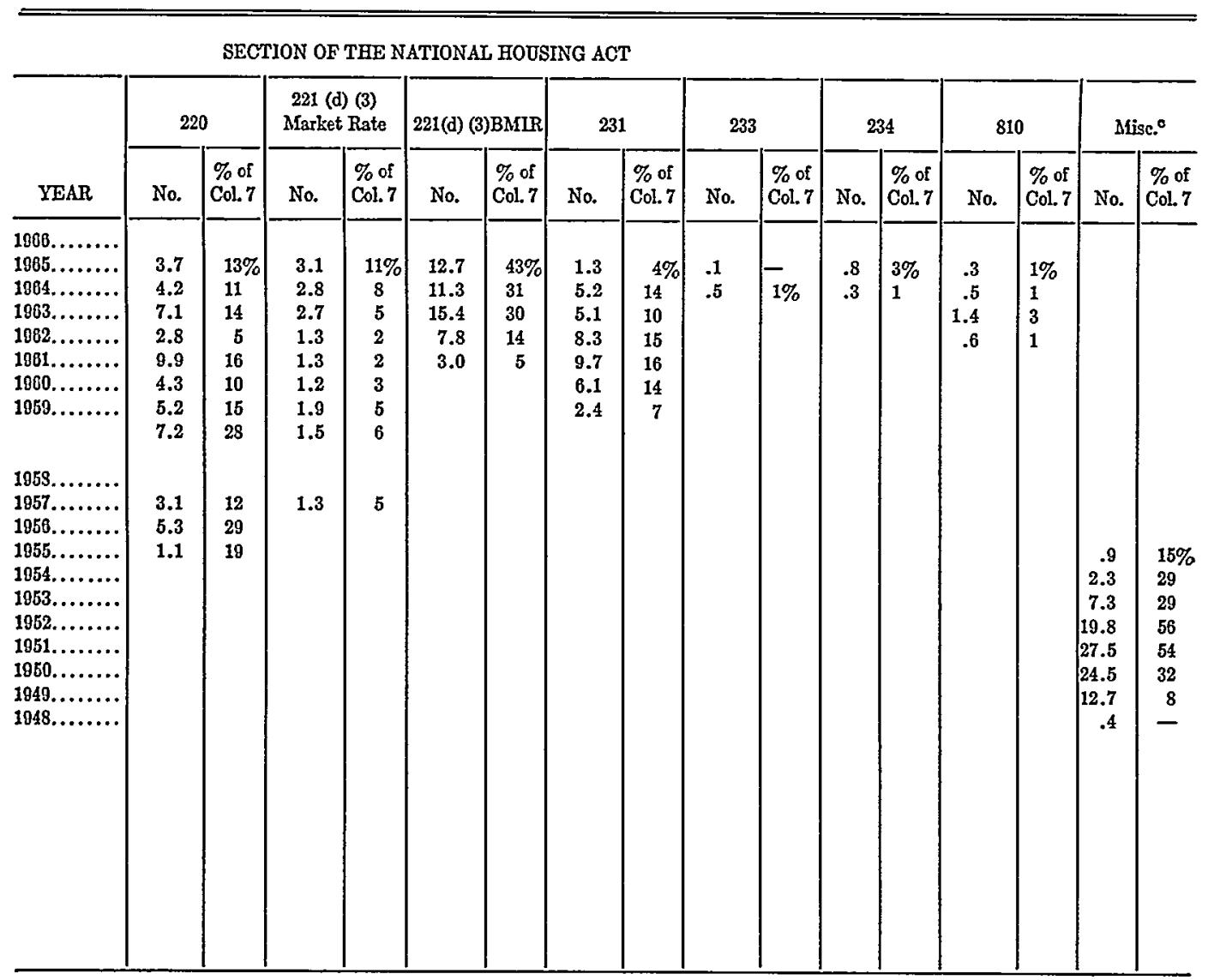

-Dats in Col. 2 for 1944-40 and in Col. 3 and 4 for 1958-40 are estimated.

bMultifamily unit totals exclude mobile housing spaces under Sec. 207, nursing home beds under Sec. 232, and armed services projects classifed as p ublio housing under Sec. 803 .

Includes Sec. 611,803 (military housing) and 908.

Figures shown in thousands of units

Source: Census Reports and Reports of the Department of Housing and Urban Development

should ask: "How effective, currently, is the FHA in the use of these powers?" Unfortunately, the facts show that FHA's current performance leaves much to be desired, and must be greatly improved if we are to meet the increasing future needs.

The chart annexed hereto as table 2 shows, among other things, the extent of FHA assistance in financing the development of multifamily housing over the twenty-seven-year period from I940 to I966. In Ig66, FHA participation was only eight per cent and in $x 965$ was only seven per cent. Over the twenty-seven year period, FHA participation ranged from six per cent in I940 and I94I (when the only FHA authorization to assist multifamily housing was the original section 207 program enacted in $193^{8}$ and on a much less liberal basis than the present section 207 program) to ninety-nine per cent in $195^{\circ}$ at the peak of the section 608 program. The average over the twenty-seven year period was about thirty-one per cent. 
The facts show that, when FHA is of a mind to do so, it can be an extremely potent influence in assisting the development and construction of multifamily housing. Over a peak six-year period, FHA was assisting multifamily housing production at an average annual rate of 87,000 units a year, compared to less than 30,000 units in rg66. It would, I think, represent a fair consensus that, today, and in the years ahead, FHA's participation in multifamily housing production ought to be in the area of at least thirty-three per cent of the total and that, when it falls below this range, any real national effort toward marked improvement of our urban areas is in very serious trouble. 